\title{
Intraosseous schwannoma of the proximal humerus with pathologic fracture
}

\author{
Jiang Huajun ${ }^{1 *} \mathbb{D}$, Qu Wei ${ }^{1}$, Wu Yuxuan ${ }^{1}$ and Yang Jingjing ${ }^{2^{*}}$
}

\begin{abstract}
Background: Intraosseous schwannomas are extremely rare in the humerus, and less than five cases have been reported previously in the literature. This is the first report of its origin in the proximal humerus with pathologic fracture. We herein present this case to discuss the reason for its rarity and share our experience of management.

Case presentation: A 55-year-old female patient presented with pain in the right shoulder, which was caused by tripping and falling over a board. Radiographs, computed tomography (CT) and magnetic resonance imaging (MRI) showed considerable tumor in proximal humerus, which connected with a fracture. For this suspected tumor, we performed two operations. Pathological examination demonstrated typical picture of a schwannoma, showing whorls and interlacing fascicles of schwannoma spindle cells. Immunohistochemistry, the tumor cells were diffusely positive for S-100 protein, SOX-10 and CD68, while they were completely negative for desmin, DOG-1, AE1/AE3 and P63. The Ki-67 index was about 10\%. No mitoses or features of malignancy were identified. The final diagnosis of intraosseous schwannoma was made. The treatment for intraosseous schwannoma with pathologic fracture includes excisional biopsy, curettage, bone allograft, and fracture fixation. The patient recovered well. After the surgery, the patient gradually regained mobility and the pain subsided. There was no recurrence after 6 months of follow-up by X-ray.
\end{abstract}

Conclusions: Although very rare, intraosseous schwannoma should be taken under consideration in the differential diagnosis of benign-appearing osseous tumor in the proximal humerus with pathologic fracture.

Keywords: Intraosseous schwannoma, Proximal humerus, Radiographs, Pathological examination, Immunohistochemistry

\section{Background}

Schwannoma is a neurogenic tumor that arises from a local proliferation of schwannoma cells in the peripheral, cranial, or visceral nerve. Intraosseous schwannomas account for less than $0.2 \%$ of primary bone tumors [1], and the most common site for intraosseous schwannoma is the mandible. To our knowledge, Intraosseous schwannomas are extremely rare in the humerus, and less than five cases have been reported previously in the literature

\footnotetext{
*Correspondence: jianghuajun112@163.com; dyyangjingjing1988@163.com 1 Department of Orthopaedics, First Affiliated Hospital of Dalian Medical University, No. 222, Zhongshan Road, Dalian 116011, China

${ }^{2}$ Department of Neurology, First Affiliated Hospital of Dalian Medical University, No. 222, Zhongshan Road, Dalian 116011, China
}

[2-5]. This is the first report of its origin in the proximal humerus with pathologic fracture. We herein present this case for discussing the reason for its rarity and sharing our experience of management.

\section{Case presentation}

A 55-year-old female patient was referred to our hospital with right shoulder pain caused by tripping and falling over a board on the same day. She had pain and restriction of movements of her right shoulder joint. Her history was notable for having antecedent pain in the right shoulder with restriction of overhead movements for about 1 year. She denied previous shoulder injury, or surgery. On presentation, the patient complained about right shoulder pain, swelling and

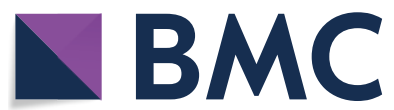

(c) The Author(s) 2021. This article is licensed under a Creative Commons Attribution 4.0 International License, which permits use, sharing, adaptation, distribution and reproduction in any medium or format, as long as you give appropriate credit to the original author(s) and the source, provide a link to the Creative Commons licence, and indicate if changes were made. The images or other third party material in this article are included in the article's Creative Commons licence, unless indicated otherwise in a credit line to the material. If material is not included in the article's Creative Commons licence and your intended use is not permitted by statutory regulation or exceeds the permitted use, you will need to obtain permission directly from the copyright holder. To view a copy of this licence, visit http://creativeco mmons.org/licenses/by/4.0/. The Creative Commons Public Domain Dedication waiver (http://creativecommons.org/publicdomain/ zero/1.0/) applies to the data made available in this article, unless otherwise stated in a credit line to the data. 
ecchymosis. On palpation, tenderness was noted all around the shoulder. The skin of the shoulder was intact, and there was no evidence of warmth, erythema, or induration. Both neurological and vascular examinations were normal.

Radiographs of the right shoulder showed a large, welldefined osteolytic tumor, which gave an appearance of endosteal scalloping and trabeculated contours on the edge of the bone lesion, involving the proximal humerus (Fig. 1A, B). No significant periosteal reaction was present, and no soft tissue mass or central calcifications were found.

Computed tomography (CT) showed considerable well-defined osteolytic lesion with cortical ballooning and thinning. The density of the tumor was homogeneous and had invaded into the cortex. An intramedullary mass elevating the periosteum was seen at the axial slice bone window and a fracture was seen at the coronal slice bone window (Fig. 1C, D).

Magnetic resonance imaging (MRI) of the right shoulder showed the tumor had invaded into the cortex and the bone lesion with associated soft tissue edema. The lesion was isointense to muscle on T1-weighted images (Fig. 2A, C), and hyperintense on T2-weighted images (Fig. 2B, D). It was noted to involve the anterior, medial, posterior aspect of proximal humerus. The shoulder joint space was uninvolved.

Because of uncertainty regarding the histological origin of the tumor, we performed an open biopsy. The operation was performed using a standard deltopectoral approach to access the proximal humerus. Intraoperative the anterolateral cortex of the proximal humerus was elevated (cortical flap). After exposing and removing the upper bony sheath, we found that the tumor was a wellencapsulated soft grayish-yellow colored mass (Fig. 3A).
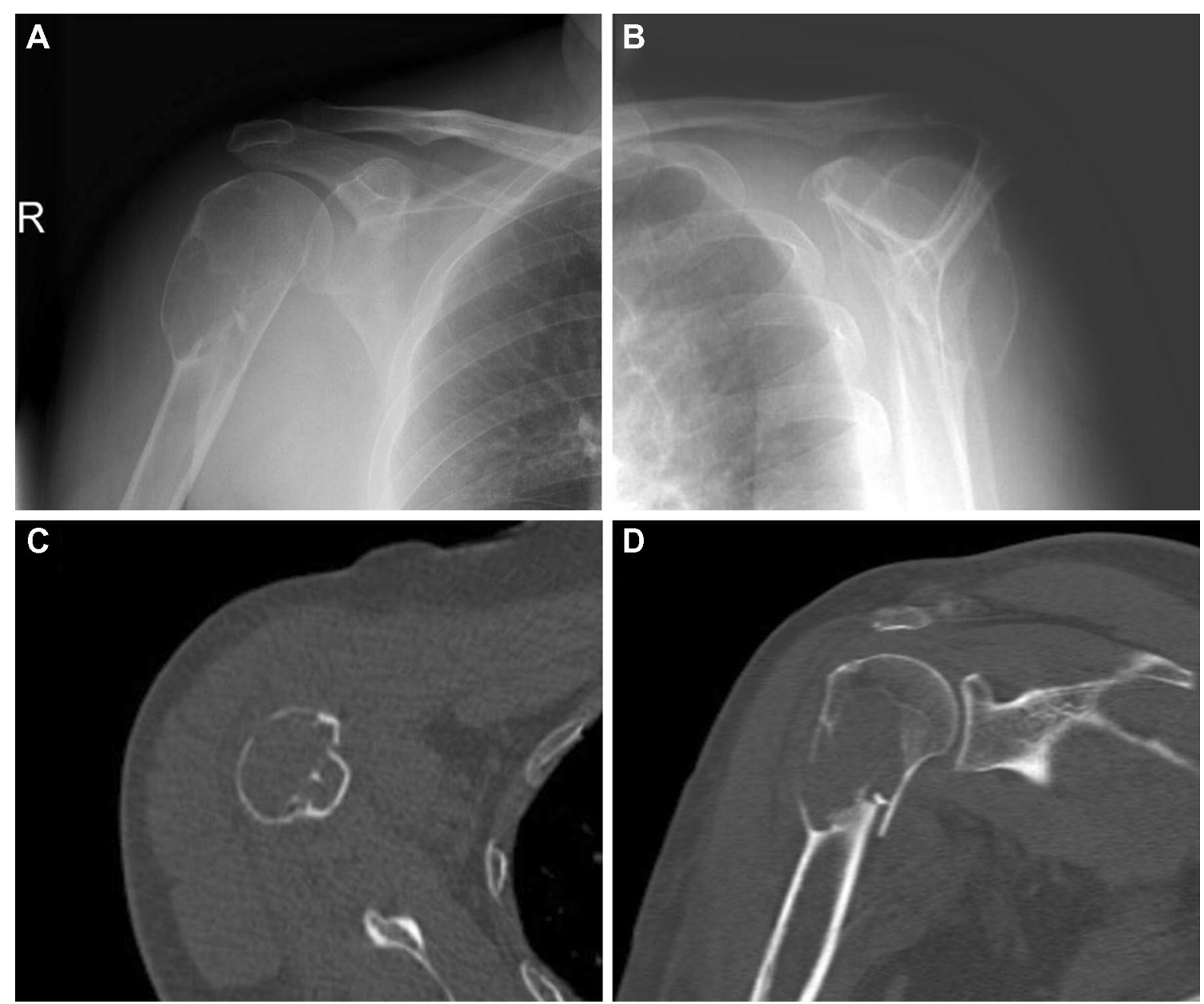

Fig. 1 Anteroposterior (A) and lateral (B) radiographs, shows an expanding, lytic lesion affecting the proximal humerus associated with scalloping of the endosteum. Computed tomography $(\mathrm{CT})$ axial slice bone window $(\mathbf{C})$ shows a intramedullary mass elevating the periosteum. Coronal slice bone window (D) shows a fracture at the proximal humerus region 

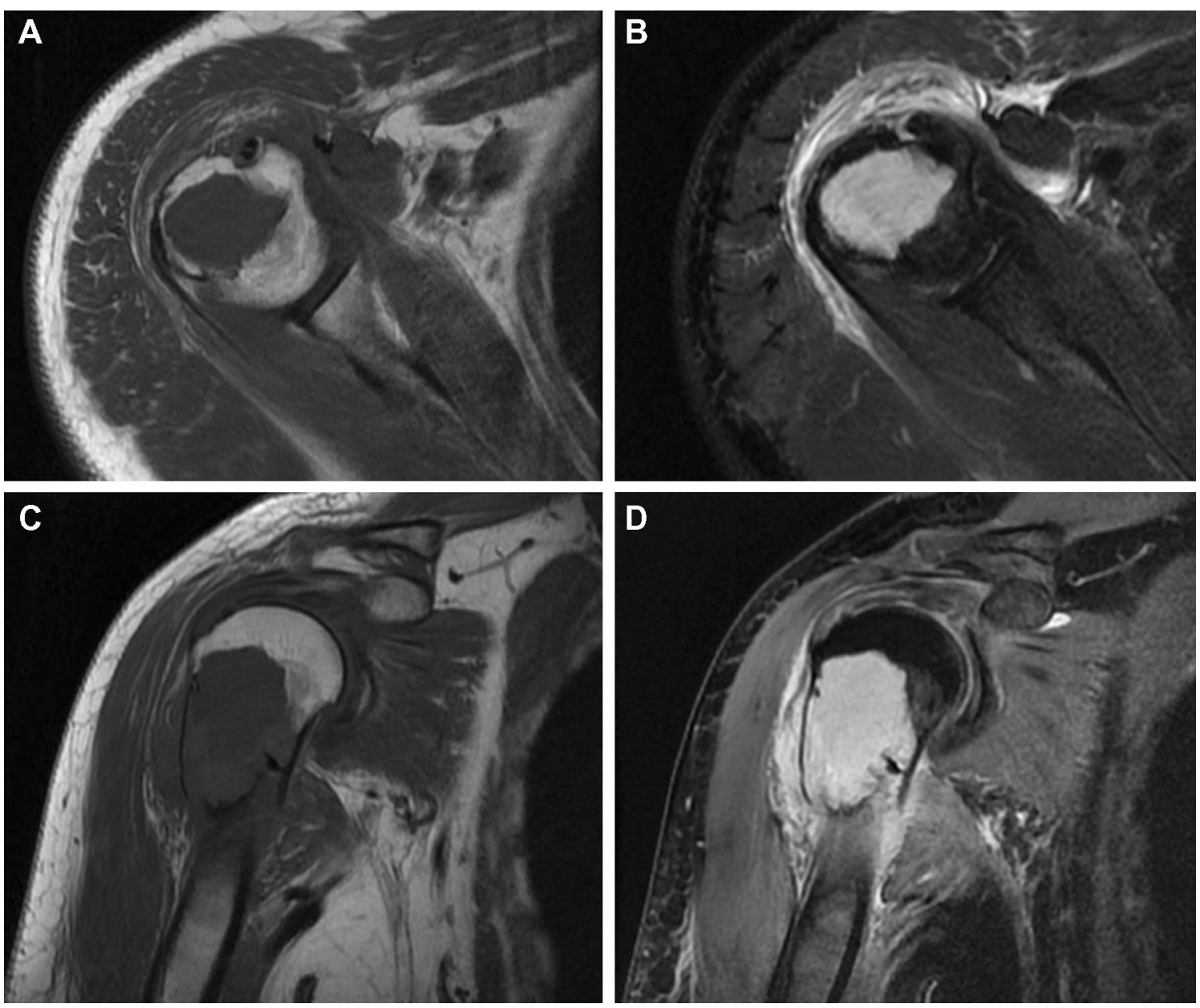

Fig. 2 T1-weighted image shows an intramedullary lesion, isointense to muscle, $\mathbf{A}$ axial image, $\mathbf{C}$ coronal image. T2-weighted image shows a hyperintense lesion associated with soft tissue edema, $\mathbf{B}$ axial image, $\mathbf{D}$ coronal image

The pathological tissue was removed and sent for histopathological analysis.

Pathological examination demonstrated typical picture of a schwannoma, showing whorls and interlacing fascicles of schwannoma spindle cells (Fig. 4A, B), and some specimens showed intratumoral bleeding (Fig. 4C, D). Immunohistochemistry for S-100 protein, SOX-10, CD68, desmin, DOG-1 (discovered on gastrointestinal stromal tumors-1), AE1/AE3, P63, Ki-67 was performed. The tumor cells were diffusely positive for $\mathrm{S}-100$ protein, SOX-10 and CD68 (Fig. 5A-C), while they were completely negative for desmin, DOG-1, AE1/AE3 and P63 (Fig. 6A-D). The Ki-67 index was about 10\% (Fig. 5D). No mitoses or features of malignancy were identified. Finally, a diagnosis of benign schwannoma with focal of actively proliferated cells was made.

Then the patient was scheduled 10 days after the biopsy for an extended curettage, bone allograft, and fracture fixation, using the same approach. Intraoperative, a complete and meticulous curettage was performed, the cavity was filled with allograft bone (Fig. 3B), and the pathologic fracture was fixated with a proximal humerus locking plate (Fig. 3C, D).

The patient recovered well. After the surgery, physiotherapy was started the day after the operation and a sling was given for comfort. The patient gradually regained mobility and pain subsided. There was no recurrence after 6 months follow-up by X-ray.

\section{Discussion}

Intraosseous schwannomas are rare benign neoplasms of the bone of which fewer than 200 cases have been described in the world literature [6]. In all of these, the majority of intraosseous schwannomas have been located in the mandible. Kito $\mathrm{M}$ and his colleagues have 

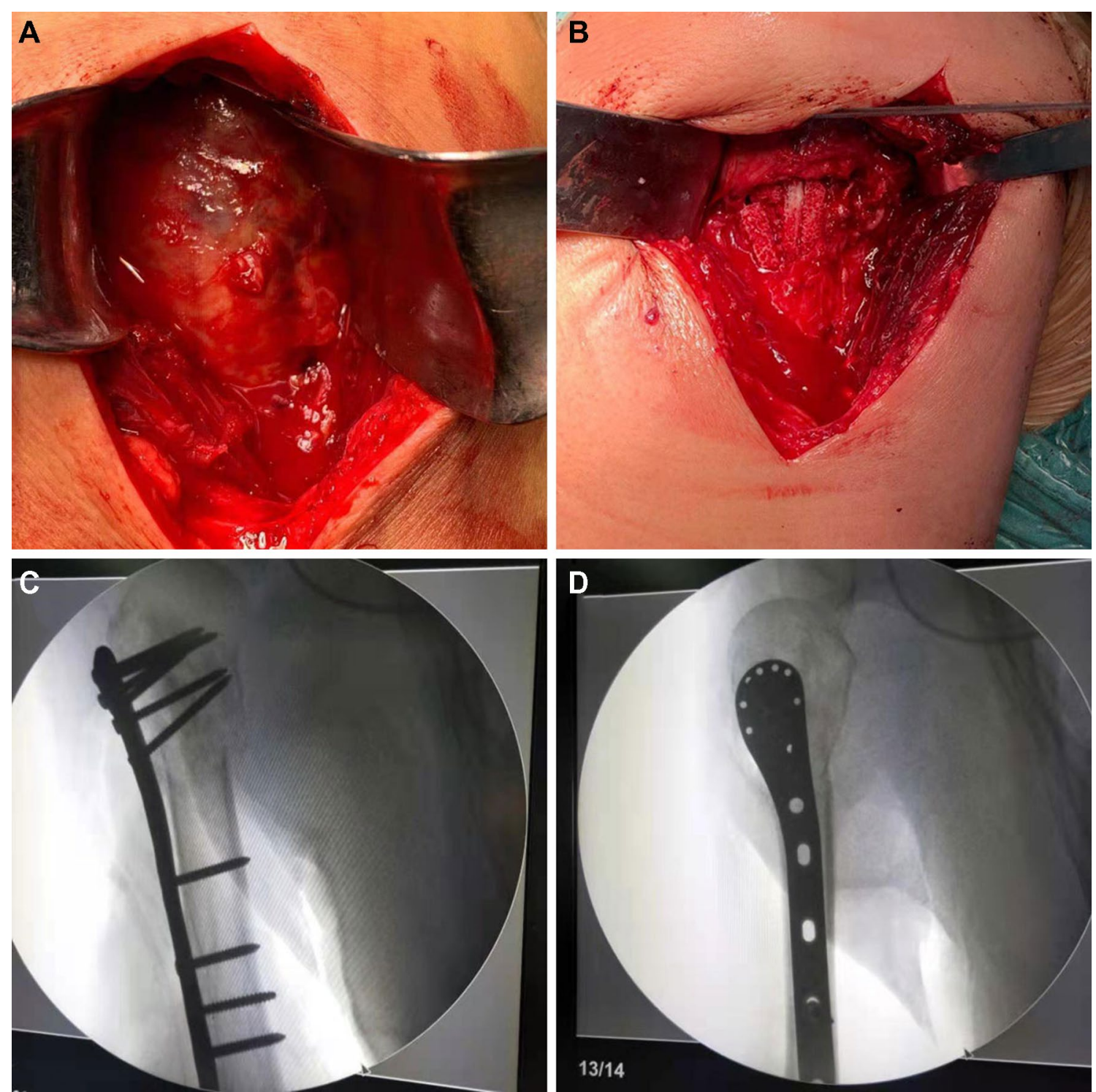

Fig. 3 A Intraoperative, the tumor was a well-encapsulated soft grayish-yellow colored mass, B the tumor was removed and the cavity was filled with allograft bone. C, D the pathologic fracture was fixated with a proximal humerus locking plate.

suggested that the high frequency in the mandible is not because of the long intraosseous course, but because the mandibular nerve consists of sensory nerves of the trigeminal nerve origin [7]. On the contrary, most intraosseous nerves are non-myelinated and participate in vasomotor functions. This may be the cause of schwannoma rarely arising in the bones of the extremities [8]. Up until now, less than five cases [2-5] have previously been reported in the humerus. In this paper, we present the first case report of an intraosseous schwannoma affecting the proximal humerus with pathologic fracture.
Clinically, intraosseous schwannoma may be present for years before becoming symptomatic, and pain may be present in about $50 \%$ of the cases, whereas no symptoms are present in about 25\% [9]. They are often discovered as an incidental finding [10]. In our case, the tumor was found after the incidence of a trivial trauma, even though the patient having antecedent pain in the right shoulder with restriction of overhead movements for about 1 year.

Preoperatively, the possibility of intraosseous schwannoma was not considered in our case because of its rarity and nonspecific clinical and radiological findings. The 

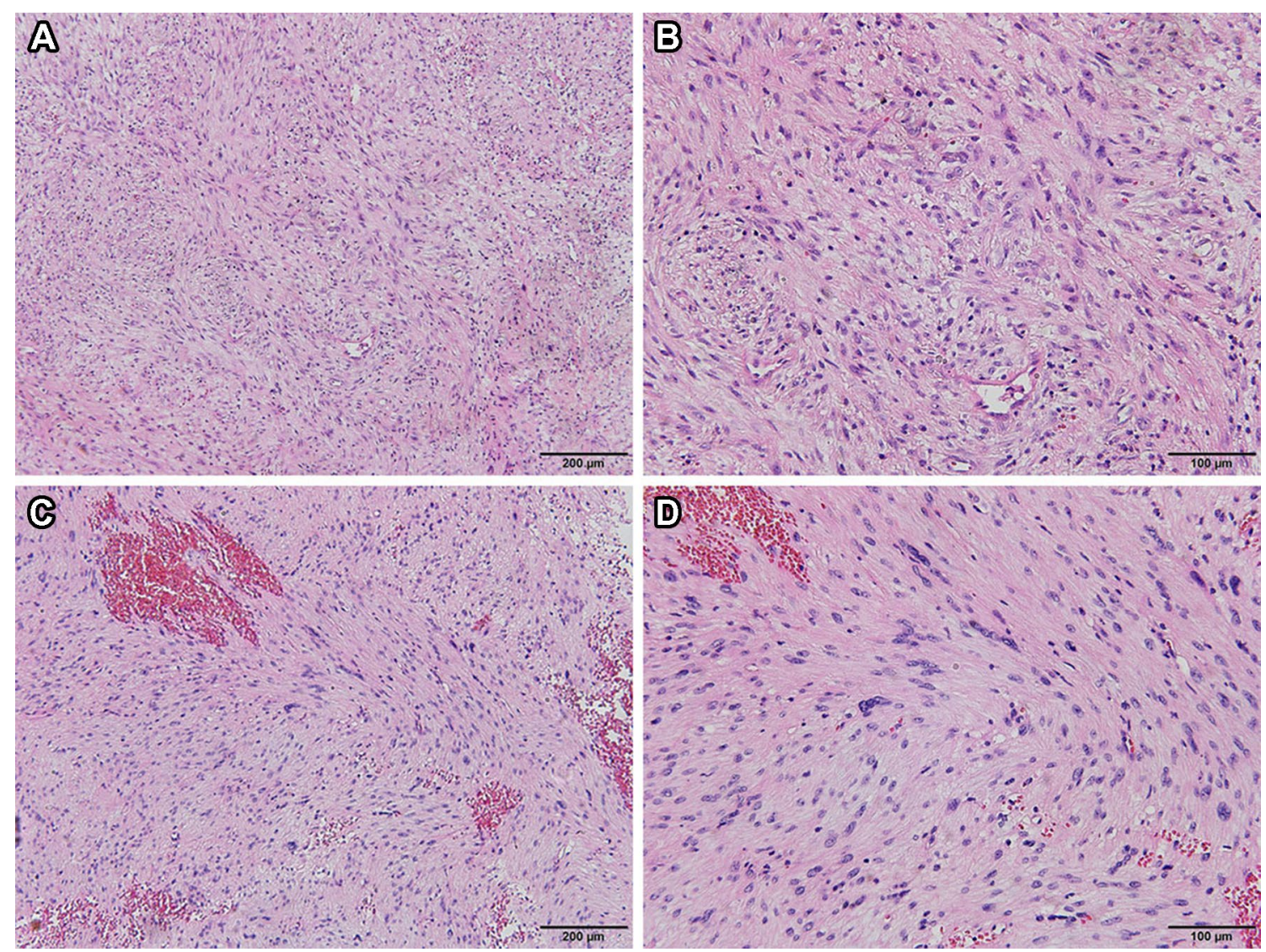

Fig. 4 Pathological examination demonstrated typical picture of schwannoma, showing whorls and interlacing fascicles of schwannoma spindle cells (A: HE 100; B: HE 200). Some specimens showed intratumoral bleeding (C: HE 100; D: HE 200)

typical radiographic appearance of intraosseous Schwannoma is a well-defined lytic lesion, sclerotic margins, lobulated or trabeculated contours, cortical expansion, and absence of central calcification $[7,11]$. Computed tomography facilitates the detection and delineation of these tumors, and MR imaging shows an isointense signal to muscle on T1-weighted images and homogeneously or heterogeneously hyperintense to fat on T2-weighted images [12]. These characteristics were all manifest in our case. However, these findings are nonspecific [13]. The final diagnosis was not made until histologic examination of tissue obtained.

Pathologically, intraparenchymal schwannomas have similar appearances to soft tissue schwannoma and demonstrate two types of cell arrangements, alternating cellular (Antoni A) and myxoid (Antoni B) areas [14]. Immunohistochemical staining can facilitate the diagnosis. In this study, we performed several immunohistochemical stainings, including S-100 protein, SOX-10, CD68, desmin, DOG-1, AE1/AE3, P63 and
Ki-67, which are used as ancillary tests for diagnosis of the tumor. Diffuse immune reactivity for S100 protein and SOX-10 is indicative of schwann cell origin. Negative staining for smooth muscle marker desmin [15], gastrointestinal stromal marker DOG-1 [16, 17], cytokeratin (AE1/AE3) [18], myoepithelial marker p63, respectively [19], are used to rule out histological differential diagnoses. In our case, pathological examination demonstrated typical picture of schwannoma, showing whorls and interlacing fascicles of schwannoma spindle cells. The diffuse immune reactivity for S-100 protein is indicative of a Schwann cell origin. The final diagnosis of intraosseous schwannoma was made.

It is remarkable that the tumor in our case showed higher CD68 staining. Generally, the degree of inflammation measured by the expression of CD68 showed a positive significant correlation with tumor size and tumor growth index [20]. This is inflammatory in nature and may contribute to the pathogenesis of schwannoma 

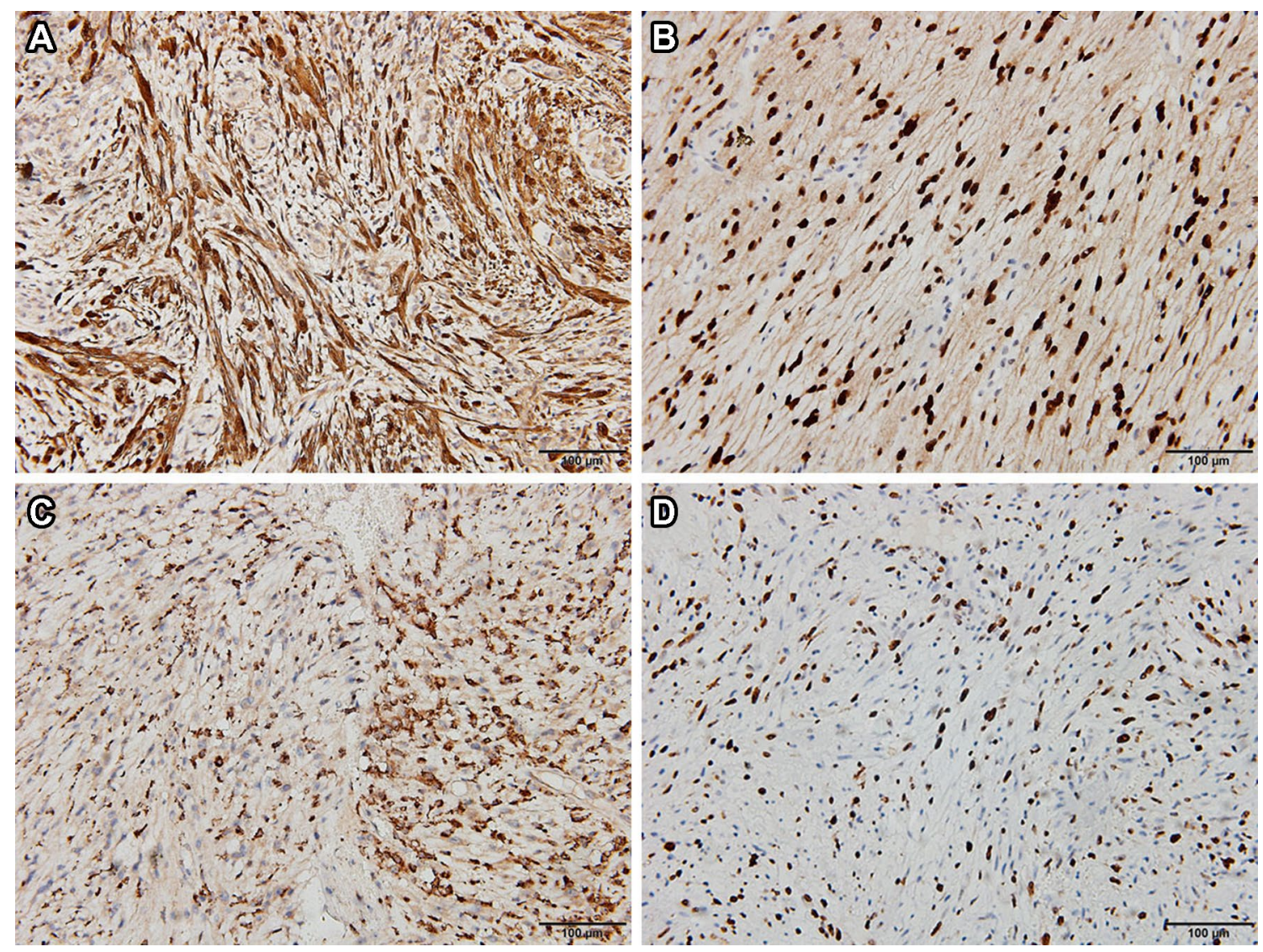

Fig. 5 Immunohistochemical analysis demonstrated the presence of A S-100, B SOX-100, C CD68 and D Ki-67(+ 10\%)

[21]. Although there is a lack of clear insight regarding the control mechanisms for oncogenesis, in our case, the tumor with higher CD68 staining likely demonstrates that the tumor volume increase is not only based on cell proliferation, but also intratumoral hemorrhage, vascularization, and inflammation, which may be produce rarefaction of the bone and lead to bone fracture after a trivial trauma.

$\mathrm{Ki}-67$ is a monoclonal antibody that provides a means of evaluating the growth fraction of normal and neoplastic human cell populations. A Ki-67 index of less than $3 \%$ is expected for a typical schwannoma. schwannomas with an index of greater than $3 \%$ are presumed to be actively proliferating and pose a theoretically higher risk for regrowth or recurrence [22]. However, Ki-67 proliferative index is variable. In a study by Imagama et al., Ki-67 index was $<1 \%$ in purely intramedullary tumors while it ranged between 18 and $25 \%$ in cases where the tumor was both intra- and extramedullary [23]. In our case, the tumor was both intra- and extramedullary. The Ki-67 index was about $10 \%$, which are presumed to be non-actively proliferating and pose a lower risk for recurrence.

Finally, the recommended treatment for intraosseous schwannomas with pathologic fracture includes excisional biopsy, curettage, bone allograft, and fracture fixation. In our case, there was no evidence of recurrence and have a good functional outcome. 

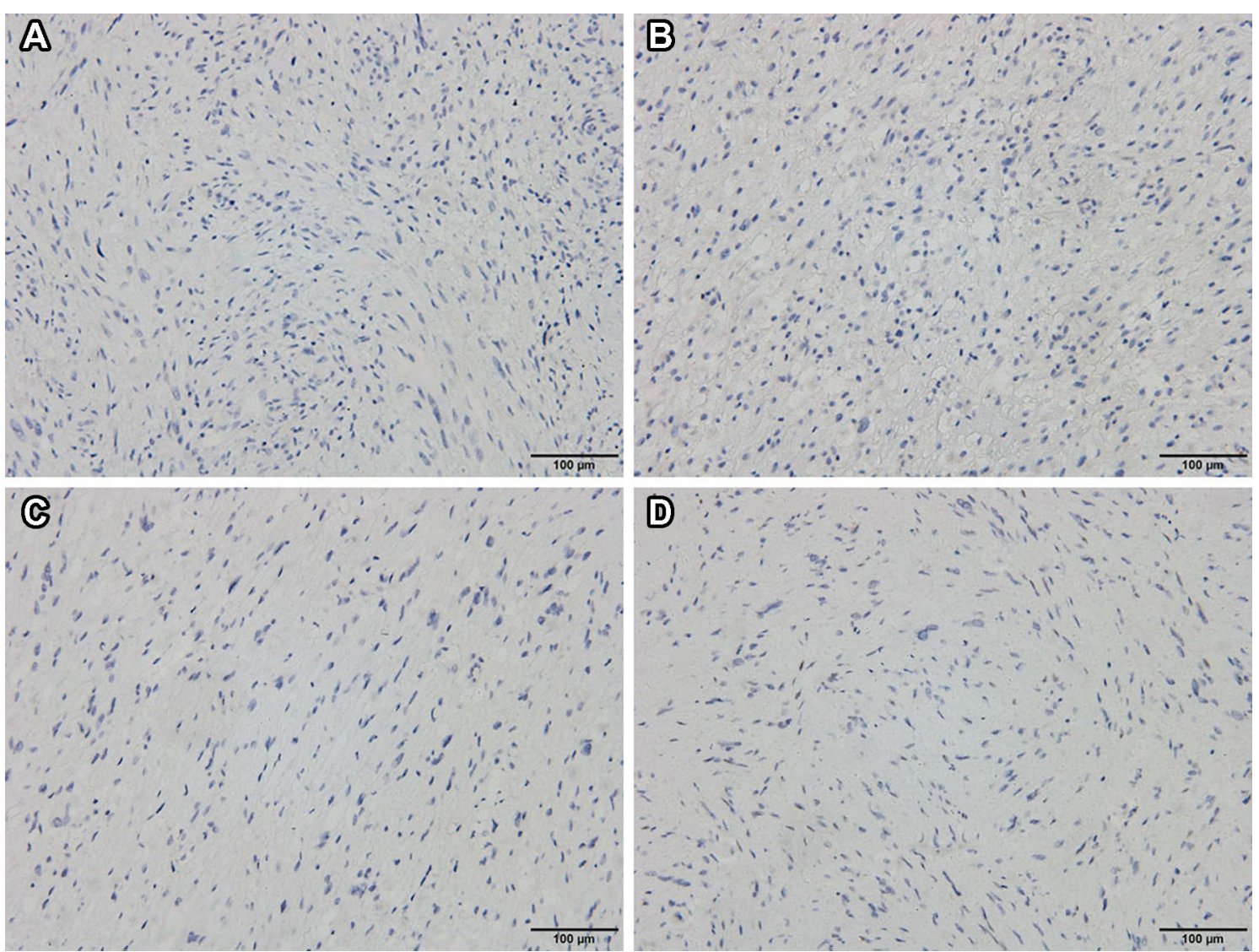

Fig. 6 Immunohistochemical analysis demonstrated the absence of A Desmin, B DOG-1, C AE1/AE3, D P63

\section{Acknowledgements}

Not applicable.

\section{Authors' contributions}

$\mathrm{JH}$ and $\mathrm{YJ}$ designed this study; $\mathrm{JH}$ and $\mathrm{YJ}$ analyzed the data and drafted the manuscript; QW and WY revised the manuscript. All authors read and approved the final manuscript.

\section{Funding}

No funding was received for this work.

\section{Declarations}

\section{Ethics approval and consent to participate}

Since no human experimentation was performed, no approval by an ethics board was required.

\section{Consent for publication}

All co-authors consent for this publication.

\section{Competing interests}

The authors declare no conflicts of interest.

Received: 5 April 2021 Accepted: 29 June 2021

Published online: 09 July 2021

\section{References}

1. Fawcett KJ, Dahlin DC. Neurilemmoma of bone. Am J Clin Pathol. 1967:47:759-66.

2. Gross P, Bailey FR, Jacox HW. Primary intramedullary neurofibroma of the humerus. Arch Pathol. 1939;28:716-8.

3. Samter TG, Vellios F, Shafer WG. Neurilemmoma of bone: report of three cases with review of the literature. Radiology. 1960;75:215-22.

4. Wirth WA, Bray CB Jr. Intra-osseous neurilemmoma. Case report and review of thirty-one cases from the literature. J Bone Joint Surg Am. 1977:59:252-5

5. Mutema GK, Sorger J. Intraosseous schwannoma of the humerus. Skeletal Radiol. 2002:31:419-21.

6. Meek RM, Sharma H, Jane MJ, et al. Solitary intraosseous schwannoma of the metatarsal bone: a case report. Foot Ankle Int. 2007;28:845-8.

7. Kito M, Yoshimura Y, Isobe K, et al. Intraosseous neurilemmoma of the proximal ulna. Int J Surg Case Rep. 2014;5(12):914-8.

8. Gordon EJ. Solitary intraosseous neurilemmoma of the tibia: review of intraosseous neurilemmoma and neurofibroma. Clin Orthop Relat Res. 1976:117:271-82.

9. Chi AC, Carey J, Muller S. Intraosseous schwannoma of the mandible: a case report and review of the literature. Oral Surg Oral Med Oral Pathol Oral Radiol Endod. 2003;96:54-65.

10. Hosalkar HS, Nussen-Lee S, Torbert JT, et al. Leg pain in a 39-year-old man. Clin Orthop Relat Res. 2005;434:282-8.

11. Hoshi M, Takada J, Oebisu N, et al. Intraosseous schwannoma of the proximal femur. Asia Pac J Clin Oncol. 2012;8(3):e29-33. 
12. Stull MA, Moser RP Jr, Kransdorf MJ, et al. Magnetic resonance appearance of peripheral nerve sheath tumors. Skeletal Radiol. 1991;20(1):9-14.

13. Afshar A, Afaghi F. Intraosseous schwannoma of the second metacarpal: case report. J Hand Surg Am. 2010;35:776-9.

14. McAleese T, Clesham K, Moloney D, et al. Intraosseous schwannoma of the femur in a patient with monoclonal gammopathy of undetermined significance. Int J Surg Case Rep. 2020;72:494-8.

15. Yin $Y$, Wang $T$, Cai YP, et al. Microcystic/reticular schwannoma of the mandible first case report and review of the literature. Medicine. 2015;94(45): e1974.

16. Ardeleanu C, Arsene D, Hinescu M, et al. Pancreatic expression of DOG1: a novel gastrointestinal stromal tumor (GIST) biomarker. Appl Immunohistochem Mol Morphol. 2009;17:413-8.

17. Hemminger J, Iwenofu $\mathrm{OH}$. Discovered on gastrointestinal stromal tumours 1 (DOG1) expression in non-gastrointestinal stromal tumour (GIST) neoplasms. Histopathology. 2012;61(2):170-7.

18. Cheng Y, Bai Q, Wu B, et al. Clinicopathologic and molecular cytogenetic analysis of 8 cases with uterine cervical ewing sarcoma: case series with literature review. Am J Surg Pathol. 2021:45(4):523-30. https://doi.org/10.1097/PAS.0000000000001674.
19. Jo VY, Fletcher CD. p63 immunohistochemical staining is limited in soft tissue tumors. Am J Clin Pathol. 2011;136(5):762-6.

20. de Vries M, Hogendoorn PC, Briaire-de Bruyn I. Intratumoral hemorrhage, vessel density, and the inflammatory reaction contribute to volume increase of sporadic vestibular schwannomas. Virchows Arch. 2012;460:629-36.

21. Ahn A, Park CJ, Cho YU, et al. Clinical, laboratory, and bone marrow findings of 31 patients with Waldenström macroglobulinemia. Ann Lab Med. 2020:40(3):193-200

22. Prueter J, Norvell D, Backous D. Ki-67 index as a predictor of vestibular schwannoma regrowth or recurrence. J Laryngol Otol. 2019;133(3):205-7.

23. Imagama $S$, Ito $Z$, Wakao $N$, et al. Differentiation of localization of spinal hemangioblastomas based on imaging and pathological findings. Eur Spine J. 2011;20:1377-84.

\section{Publisher's Note}

Springer Nature remains neutral with regard to jurisdictional claims in published maps and institutional affiliations.
Ready to submit your research? Choose BMC and benefit from:

- fast, convenient online submission

- thorough peer review by experienced researchers in your field

- rapid publication on acceptance

- support for research data, including large and complex data types

- gold Open Access which fosters wider collaboration and increased citations

- maximum visibility for your research: over $100 \mathrm{M}$ website views per year

At BMC, research is always in progress.

Learn more biomedcentral.com/submissions 